\title{
II. INTERNATIONAL LAW, THE UNITED KINGDOM AND DECISIONS TO DEPLOY TROOPS OVERSEAS
}

\section{A. Introduction}

This short article considers the two primary legal frameworks that can operate to control decisions by a State, in this case the UK, to deploy troops to conflict or postconflict zones-British constitutional law and international law, and how they have both been thrown into sharp relief by the continuing debate about the possible adoption by the House of Commons of a non-statutory war powers resolution.

Historically the role of Parliament in such decisions has been more significant politically than legally, in that the 'prerogative' nature of the decision to go to war has meant that legally speaking it belongs to the Crown, which nowadays means the executive branch of government (in the UK the Cabinet, or often a small group within the Cabinet known as the 'War Cabinet', more pejoratively the 'Sofa' government under Prime Minister Blair). ${ }^{1}$ Politically though, for the Government of the day, it is often important to have Parliament on its side, particularly if it has decided to prosecute a controversial war that may become unpopular over time, so that in Kosovo, Iraq and Afghanistan Parliament was significantly involved in debates over the war aims as well as the international morality and legality of the interventions, both during and often before the wars started. It is argued here that this dynamic, where formal constitutional legal constraints are few, but international legal constraints are applicable (in terms of rules governing both the use of force and the conduct of hostilities), ${ }^{2}$ means it is international law that should play an increased role in helping to shape such decisions. However, as shall be seen, this role is played out in political fora and in non-judicial mechanisms of accountability and review rather than in the Courts.

The Government appeals to international law to garner support for, and bolster the legitimacy of, its military interventions, but in so doing it opens itself up to counterarguments about the legal basis of the war. This article considers in general terms such Parliamentary debates and the role of international law within them. Furthermore, this greater Parliamentary involvement has culminated in current reform proposals that would in a sense formalize and constitutionalize the need for prior Parliamentary approval of decisions to deploy. As will be seen, however, the recent proposal for a resolution to be adopted by Parliament embodying this procedure is a weak affair, unlikely, if it were to be adopted, to radically change current practice, and unable to provide Parliament with more objective legal advice on the international legal basis of the operation, something that is strongly argued for here. In addition, the proposal will not lead, by itself, to the development of a right of review by the British Courts.

\footnotetext{
1 See Conservative Democracy Task Force, An End to Sofa Government: Better Working of Prime Minister and Cabinet (2006).

2 The jus ad bellum and the jus in bello respectively-see Y Dinstein, War, Aggression and Self-Defence ( $4^{\text {th }}$ edn, CUP, Cambridge, 2005), and Y Dinstein, The Conduct of Hostilities under the Law of International Armed Conflict (CUP, Cambridge, 2004). For arguments that there is an emerging legal regime to govern post-conflict situations - a jus post bellum - see C Stahn and JK Kleffner (eds), Jus Post Bellum: Towards a Law of Transition from Conflict to Peace (TMC Asser, The Hague, 2008).
} 


\section{B. The Prerogative Power to Deploy Troops}

AV Dicey defined prerogative powers as 'historically and as a matter of actual fact nothing else than the residue of the discretionary or arbitrary authority, which, at any given time, is in the hands of the Crown'. ${ }^{3}$ The presence and exercise of prerogative power has two serious consequences for the rule of law and democratic accountability. First 'while Parliamentary approval is not generally needed before action is taken, Ministers [remain] responsible to Parliament for their policies and decisions'. ${ }^{4}$ Second, the Courts have no power to review the decisions of the Crown on the disposition and use of the UK's armed forces. ${ }^{5}$ Given that prerogative powers by-pass normal methods of democratic control, there is a need to re-evaluate the balance between the necessity of allowing the effective prosecution of war and the demands of democratic accountability in the modern era. There is certainly a strong view that the deployment of troops and the waging of war, or more generally 'the exercise of the physical might of the modern state' should be subject to greater democratic control. ${ }^{6}$ It is argued in this article that a major factor in the increasing pressure for reform is greater political and public awareness and advocacy of international law.

The weaknesses of the British constitution on matters of deployment of troops have been exposed by recent conflicts. It is true that the Bill of Rights of 1689 asserted constitutional superiority over the armed forces when it declared that the 'raising or keeping of a standing army within the Kingdom in time of peace, unless it be with the consent of Parliament', was against the law. However, the purpose of this part of the Bill was to prevent the King establishing his own army. Parliamentary authority was asserted over the standing army, not over each deployment of troops. The Parliamentary power to withdraw authority for the maintenance of an army is not a realistic control in the modern age. Although regular legislation is required to renew Parliamentary authority, it is adopted as a matter of course. ${ }^{7}$

The reality of the exercise of prerogative powers in the areas of foreign affairs and the disposition of armed forces is shown by the exchange in the House of Commons in 1982 when negotiations were taking place for the settlement of the Falklands conflict in the period between the Argentinian invasion and the arrival of the British task force to defend the islands. The leader of the Opposition, Neil Kinnock, claimed that 'the House of Commons has the right to make judgment on this matter before any decision is taken by the Government that would enlarge the conflict'. In response, the Prime Minister, Margaret Thatcher, declared that 'it is an inherent jurisdiction of the Government to negotiate and reach decisions. Afterwards the House of Commons can pass judgment on the Government'.

3 AV Dicey, Introduction to the Study of the Law of the Constitution $\left(10^{\text {th }}\right.$ edn, Macmillan, London, 1959) 424-425.

${ }^{4}$ AW Bradley and KD Ewing, Constitutional and Administrative Law $\left(14^{\text {th }}\right.$ edn, Longman, London, 2007) 323.

${ }^{5}$ China Navigation Co Ltd v Attorney General [1932] 2 K.B. 197 (Court of Appeal). Chandler $v$ Director of Public Prosecutions [1964] AC 736 (House of Lords). See P Rowe, Defence: The Legal Implications (Brassey's, London, 1987) 3. There is a discernible trend to review the prerogative in other areas - L Lester and D Oliver (eds), Constitutional Law and Human Rights (Butterworths, London, 1997) $250 . \quad{ }^{6}$ Bradley and Ewing (n 4) 343.

7 S De Smith and R Brazier, Constitutional and Administrative Law $\left(8^{\text {th }}\right.$ edn, Penguin, London, 1998) 217.

${ }^{8}$ Hansard, HC vol 23, cols 597-8 (11 May 1982). 
The method by which the lower house passes judgment on the Government can vary, either by unamendable procedural motions which may be voted upon, and occasionally by an amendable substantive vote; the choice being one for the political judgment of the Government and not one dictated by legal requirements. There were substantive votes in the Korean conflict, Suez and the Gulf Conflict of 1991; but not in the case of the Falklands or Kosovo. ${ }^{9}$ The debates prior to the invasion of Iraq in 2003 did culminate in a substantive vote in the House of Commons on 18 March, two days before the invasion. On the other hand, there has been no vote in Parliament concerning the deployment of British troops in Afghanistan. ${ }^{10}$

In summary, in the British political system as it relates to decisions to deploy troops overseas, the democratic deficit is so severe that we might question whether we have a system that is little different from that which surrounded the king in the $14^{\text {th }}$ and $15^{\text {th }}$ centuries. FW Maitland portrays the monarch of that time as 'the ruler of the nation, the commander of its armies and its fleets', advised not by parliament (which did exist in a very early form) but by the king's council, the members of which 'can be dismissed by the king whenever he pleases; they are sworn to advise the king according to the best of their cunning and discretion'. 'The function of the council ... is to advise the king upon every exercise of the royal power'. ${ }^{11}$ It would be easy to compare the modern Prime Minister and his ministerial colleagues in formal or informal War Cabinets to the King and his Council, but it is not necessarily as straightforward as that. Indeed, although the medieval King had untrammelled power on paper, there were increasing pressures from Parliament, from his subjects (soldiers and civilians), and from his treasury that meant that in political terms waging war was not as simple as might appear from the constitutional framework. ${ }^{12}$ In modern times, there are similar pressures, and although the British constitutional legal framework is still limited, there is increasing pressure for reform-an issue that will be returned to.

Furthermore, in the era of globalization it is true to say that 'national democratic politics cannot be understood without reference to international forces', ${ }^{13}$ no more so than in decisions to deploy combat troops to foreign lands. It must not be forgotten that Britain has since 1945 become part of a wider international institutional and legal order, which may affect its ability to wage war. In different areas of decision-making, sovereignty has been limited by European law, both of an economic nature from the EC (now the EU), and of a human rights kind from the Council of Europe. The question of whether these and other international legal frameworks and institutions have restricted the Government's prerogative powers in military matters is the issue to be considered next; first by looking at their impact in the House of Commons, and then before the Courts.

\section{International Law on the Use of Force before the House of Commons}

With British constitutional law providing little by way of legal limitation on the prerogative powers of the Government to deploy troops, the spotlight turns on

${ }^{9}$ HC Foreign Affairs Committee, Fourth Report 1999-2000, HC 28-I, para 166 (7 June 2000).

${ }^{10}$ HC Research Paper 08/88, 'Parliamentary Approval for Deploying the Armed Forces: An Introduction to the Issues' 14 (27 November 2008).

${ }_{11}^{11}$ FW Maitland, The Constitutional History of England (CUP, Cambridge, 1931) 197-199.

12 ibid 324-329.

13 S Marks, The Riddle of All Constitutions (OUP, Oxford, 2000) 100. 
international law as a means of restricting decisions of government. Methods of enforcement at the international level are limited, particularly when bearing in mind the fact that Britain possesses the power of veto in potentially the most effective executive organ dealing with matters of peace and security-the UN Security Council. Attention therefore turns to whether international law has any role in executive decision-making, or in key Parliamentary votes, at the national level. While the Courts have a limited role in this respect, relatively recent Parliamentary debates on Kosovo and Iraq have been dominated by discussions about the international legal bases of these military actions involving British troops.

One case involving the UK that was litigated before the International Court of Justice concerned events in the Corfu Channel in the immediate post-war period; a case brought by the UK against Albania in 1947 following the mining of British warships in the Channel a year earlier. The case shows the UK challenging the international legal rules governing the use of force by claiming that its minesweeping operation, taken in response to the loss of its ships, threatened neither the territorial integrity nor the political independence of Albania and therefore did not breach article 2(4) of the Charter. The Court dismissed the argument, but found for Britain on the issue of the destruction of the warships. ${ }^{14}$ Though in effect found to be in breach of international law itself, both the Government and the House of Commons were only concerned with the task of recovering compensation from Albania, something that was finally achieved in $1996 .{ }^{15}$

Though older forms of waging war (gunboat diplomacy, armed reprisals, punitive expeditions, humanitarian interventions ...) were outlawed in the post-1945 era, Britain was still prepared to use a form of gun-boat diplomacy in the Corfu Channel. Furthermore, in 1956 it launched with France what was arguably a punitive expedition to secure the Suez Canal against Egyptian nationalization. The Government argued that it was lawful as a form of protection of nationals, against the advice of the Government's Law Officers, forcing Prime Minister Anthony Eden to declare 'lawyers are always against us doing anything. For God's sake keep them out of it. This is a political affair'. ${ }^{16}$ As the operation developed and the wider conspiracy (with Israel) revealed, there was increasing criticism of the Government's policy, and though it did narrowly survive votes in the House of Commons before the deployment of

14 Corfu Channel Case (Merits), 1949 ICJ Rep 4 17-22, 35.

15 ND White, Democracy Goes to War: British Military Deployments under International Law (Oxford University Press, Oxford, 2009) 48, n 76. In 1992, the parties to the Corfu Channel case announced that they had settled their differences and in 1996 the Albanian Government settled the British claim for compensation by paying \$US 2 million-see Hansard HC vol 284 col 224WA (31 October 1996) in (1996) 67 Brit YB Int L 818-819.

${ }^{16}$ On 16 October 1956 at a meeting of ministers cited in A Nutting, No End of a Lesson: The Story of Suez (Constable, London, 1967) 95. On the legal advice given in 1956, see G Marston, 'Armed Intervention in the 1956 Suez Canal Crisis: Legal Advice Tendered to the British Government' (1988) 37 ICLQ 807, where it is stated that 'the Law Officers [the Attorney General and the Solicitor General] were considering whether to resign' given their doubts about the legality of the intervention war as stated by the Lord Chancellor (Viscount Kilmuir) who justified the intervention in the House of Lords as being one of 'self-defence [which] includes a situation in which the lives of a State's nationals abroad are threatened and it is necessary to intervene on that territory for their protection'-Hansard HL vol 199 cols 1349-50 (1 November 1956). 
forces ${ }^{17}$ the mounting criticism (especially by the United States) of the intervention and its legality, contributed to the Government's decision to withdraw and accept a UN peacekeeping force. ${ }^{18}$

While protection of nationals was an unconvincing justification for the Suez operation, humanitarian intervention to protect the Albanian population of Kosovo in 1999 was convincing enough, although the Government had to continually reassure the House of Commons that the bombing campaign was justified and above all was working. Interestingly the House of Commons Foreign Affairs Select Committee reported a year after the bombing campaign that it viewed the war as illegal though morally justified, ${ }^{19}$ when at the time of the bombing the vast majority of the House of Commons were convinced by the argument that humanitarian intervention in support of Security Council resolutions was both morally and legally justified, resulting in a lack of political will even to vote on procedural motions in the House. There was plenty of debate in Parliament and in the country at large, but no opportunity was fashioned to reflect this in a formal vote in the House of Commons in support of the bombing campaign. ${ }^{20}$

Thus in the modern era the UK has a track record of relying on controversial (often pre-UN Charter) legal justifications for its military interventions. While the UN Charter prohibited the threat or use of force, it did allow for States to defend themselves from armed attack, as well as take military enforcement action under UN Security Council authority given under Chapter VII. ${ }^{21}$ The UK relied on more solid legal grounds of self-defence in taking military action against Argentina in 1982 to remove it from the Falklands. There was no question of any significant criticism of the (often brutal) military campaign in Parliament or in the country, nor more profoundly the British right to the islands. The Argentinian invasion deepened the House of Commons' will not only to defend the islands, but also not to negotiate on the issue of its sovereignty. Only the sinking of the Argentinian warship the General Belgrano outside the exclusion zone proved to be a thorny issue that undermined Parliament's conviction that this was not only a war conducted in accordance with international law, but was above all a just war. ${ }^{22}$ No vote in the House of Commons was taken on the issue of the prosecution of the war despite heavy losses, and none was really necessary given bipartisan support. In 1985, after lingering disputes about the necessity and legality of the sinking of the Belgrano, the Government won a vote in Parliament endorsing its decision. ${ }^{23}$

The justification of self-defence and the need to eliminate a substantial terrorist threat also proved sufficient for the Government to carry the House of Commons without a vote being forced in the war in Afghanistan launched in October 2001 in response to the attacks on the United States of 9 September 2001 ('9/11'). The claim of self-defence was not as clear cut as in the case of the Falklands, being both a collective one - to act alongside the United States - and one directed at a state where the terrorist

\footnotetext{
17 Hansard HC vol 558 cols 311-12 (13 September 1956); Hansard HC vol 558 col 1378 (30 October 1956).

19 HC Foreign Affairs Select Committee (n 9), paras 124-144.

20 White (n 15) 225-235. ${ }^{21}$ UN Charter 1945, arts 2(4), 42 and 51.

22 W Little, 'Anglo-Argentine Relations and the Management of the Falklands Question' in P Byrd (ed), British Foreign Policy under Thatcher (Philip Allan, Oxford, 1988) 138.

${ }^{23}$ Hansard HC vol 73 cols 732-836 (18 Feb 1985); White (n 15) 173-182.
} 
organization responsible for the attack was based. However, the numerous debates on 9/11 and Afghanistan in the House of Commons have not revealed any significant dissent and there have been no concerted challenges or votes on the matter. In 2001 the Prime Minister, Tony Blair, spoke about defending civilised beliefs against the terrorist threat and acting in a just cause. ${ }^{24}$ The continuing presence of British troops is consistently linked back to the attacks of $9 / 11$ - to prevent Afghanistan from becoming once again a source of terrorist attacks - even though the legal basis for the presence of British troops has (largely) changed from that of self-defence to Chapter VII authority from the Security Council, combined with the consent of the Government of Afghanistan. $^{25}$

Chapter VII authority has proved sufficient in the past to carry the Government's decisions to go to war both in Korea in 1950 and the Gulf in 1991, though in both cases decisions to deploy troops to aid South Korea and Kuwait alongside the United States were already made on the basis of collective self-defence. Thus in Korea troops had already been sent when a substantive vote was held; ${ }^{26}$ whereas in the case of Kuwait in 1990-1991, the long interval between the invasion by Iraq and the use of force to liberate Kuwait, meant that the Opposition in the House of Commons had more of a chance to test the government on its strategy, including the legal basis of the operation, and in part succeeded in persuading the Government to help secure a Security Council resolution (Resolution 678 of November 1990), at least as an 'additional' legal basis to that of collective self-defence. The Government readily won a procedural vote in September 1990 and another immediately before the hostilities on 15 January 1991, though a substantive vote was not held until four days after hostilities had commenced on 17 January. $^{27}$

Though the UK helped shape the development of coalitions of the willing acting under Security Council authority, it stretched that loose system beyond breaking point in 2003 when it joined the United States in invading Iraq because of the failure of Iraq to disarm in accordance with Security Council Resolution 687 adopted following the conflict in 1991. The inadequacies of Resolution 1441 agreed in November 2002, and the frightening prospect of supporting an American doctrine of pre-emptive defence, led to much greater pressure on the Government in the House of Commons in the lead up to the war, and many attempts at accountability for the decision to invade thereafter, culminating in the announcement of the current inquiry into Iraq made in June $2009 .^{28}$ That inquiry has revealed that the legal advice given to the government was by no means as unequivocal as was made public at the time. ${ }^{29}$ Nevertheless, in

24 Hansard HC vol 372 col 814 (8 October 2001).

25 Starting with SC Res 1386 (20 Dec 2001); White (n 15) 200-204.

26 Hansard HC vol 477 cols 485-490 (5 July 1950); White (n 15) 96-104.

27 Hansard HC vol 177 col 883 (7 Sept. 1990); Hansard HC vol 183 cols 743 (15 Jan 1991); Hansard HC vol 185 col 31 (21 Jan 1991).

28 Prime Minister Gordon Brown announced the establishment of the inquiry in the House of Commons on 15 June 2009, its terms of reference being 'to consider the period from summer 2001, before military operations began in March 2003, and the UK's subsequent involvement in Iraq up to the end of July 2009. The Prime Minister told the House of Commons: "the Iraq Inquiry will look at the run-up to the conflict, the conflict itself and the reconstruction." The objective is to learn the lessons from the events surrounding the conflict'-http:iraqinquiry.org.uk/faq.aspx.

29 See evidence given to the Inquiry by Sir Michael Wood, Foreign Office Legal Adviser in 2003, on 26 January 2010, http://www.iraqinquiry.org.uk/media/43614/100126amwood.pdf; and Elizabeth Wilmshurst, Deputy Legal Adviser at the FCO in 
March 2003 a substantive vote in the House of Commons two days before the invasion was won relatively easily by the Government, ${ }^{30}$ the House being persuaded by the release of a sanitised version of the Attorney General's advice that there was a legal basis for the invasion in Resolution 678 of 1990, and by the Government's reassertions that there was a real threat from Iraq. ${ }^{31}$ In reality though the use of force was taken without UN authority and without any real threat being present, making it a violation of the rules prohibiting the use of force in the UN Charter and in customary international law. ${ }^{32}$

International law plays a significant role in Parliamentary debates on wars and postconflict situations, but the actual decision to deploy troops is, despite the debates and occasional votes held in the House of Commons, a governmental issue, and Parliament has not been prepared to challenge it even when the legal basis of the war is clearly suspect. Though the Attorney General's advice was strengthened for Parliament in the case of Iraq, the House of Commons seemed to accept it, paying no regard to the considerable criticism it received from academics and elsewhere (shown in the fuller version of the Attorney General's advice released in 2005, and the evidence given to the Iraq Inquiry in January 2010). This unwillingness to challenge decisions to deploy troops is also found in the Courts, where, for example, CND's challenge to the legality of the Iraq war was met with incredulity by the Court of Appeal, Lord Justice Brown declaring that is was most unlikely that the Government made a mistake on the law since 'it has access to the best advice, not only from law officers but also from a number of specialists in the field'. ${ }^{33}$

\section{International Law on the Use of Force Before UK Courts}

The dismissal of CND's challenge to the legality of the decision to go to war against Iraq is typical of the attitude of British Courts towards the prerogative power to deploy troops. Attempts have been made to indirectly impugn the decision to go to war; for example Margaret Jones defended her involvement in criminally damaging an RAF base on 13 March 2003 on the grounds that she was trying to prevent a greater crime being committed - the crime of aggression against Iraq. The House of Lords agreed

2003 - http://www.iraqinquiry.org.uk/media/44211/20100126pm-wilmshurst-final.pdf. Both considered the use of force to be illegal as a matter of international law. For Lord Goldsmith's (the Attorney-General at the time) more equivocal evidence of 27 January 2010 see http://www. iraqinquiry.org.uk/media/43803/100127-goldsmith.pdf. The Attorney General's advice released on 17 March 2003 was to the effect that the authority to use force against Iraq given in SC Resolution 678 (1990) was revived by a material breach by Iraq of Resolution 1441 (2002) and earlier disarmament resolutions - see Hansard HC vol 401 col 760 (18 March 2003) when Prime Minister Tony Blair relied on this argument in proposing a substantive vote. The Attorney General's full advice was not released until 28 April 2005, in which, in contrast, he concluded that 'if the matter ever came before a court', that court 'may well' conclude that Resolution 1441 did require a 'further Council decision in order to revive the authorization in' Resolution 687; http:// www.guardian.co.uk/politics/2005/apr/28/election2005.uk.

30 Hansard HC vol 401 cols 906-11 (18 March 2003).

31 Hansard $\mathrm{HC}$ vol 401 cols 760-4 (18 March 2003).

32 White (n 15) 252-264. See also D McGoldrick, From 9-11 to the Iraq War 2003 (Hart, Oxford, 2004) 47-86.

33 The Campaign for Nuclear Disarmament $v$ The Prime Minister of the United Kingdom [2002] EWHC 2777, para 44. 
that aggression was a crime under international law but stated that it was not part of domestic criminal law; this was bolstered by Lord Bingham stating that the "courts will be very slow to review the exercise of prerogative powers in relation to the conduct of foreign affairs and the deployment of armed services'. ${ }^{34}$

While the courts have accepted that the Human Rights Act of 1998 is applicable to civilians held in detention centres in Iraq, ${ }^{35}$ and in certain circumstances to British soldiers in that country, ${ }^{36}$ they have been unwilling to consider arguments under the Act that could amount to questioning the legality of the conflict. When Rose Gentle, the mother of a soldier killed by a roadside bomb in Iraq, claimed that part of the British Government's obligations under the right to life was to hold an inquiry into the wider circumstances surrounding her son's death, the Law Lords declined her request; Lord Bingham stating that article 2 of the European Convention had never been 'held to apply to the process of deciding upon the lawfulness of resort to arms' even though decisions to go to war resulted in loss of life. He did feel, however, it necessary to justify his decision further saying that 'the lawfulness of military action has no bearing on the risk of fatalities', citing the effectiveness (from Japan's perspective) of its attack on Pearl Harbour in December 1941-illegal but minimizing Japanese casualties. More importantly he stated that Fusilier Gentle had been killed after 'Security Council Resolution 1546 had legitimated British military action in Iraq, so that such action was not by then unlawful even it had earlier been so'. Baroness Hale was heavily critical of the Attorney General's advice on the legality of the invasion of Iraq in 2003, and expressed great sympathy with the mothers of dead soldiers, but ultimately decided that 'the lawfulness of war is an issue between states, not between individuals or between individuals and the State'. ${ }^{37}$

However, with the prerogative in other areas increasingly coming within the purview of the Courts, judicial scrutiny of decisions to go to war may be closer than is commonly thought. Leading constitutional lawyers have written that 'the need for military effectiveness in the defence of the realm does not mean ... that the law of judicial review has no role to play in this as in other areas of governmental activity,. ${ }^{38}$ Though the recent transformation of the Appellate Committee of the House of Lords into the Supreme Court in October 2009 is in many ways simply a change of name, it may embolden the Court to take on the supreme challenge for a constitutional court and take an opportunity to review a controversial future decision to go to war. Fear of this eventuality may partly explain the Labour Government's preference for a nonstatutory war powers resolution reviewed in the next section.

$34 R$ vones [2006] UKHL 16, paras 29-30.

35 The case of Baha Mousa who died while in a British detention facility in Iraq- $R$ (Al-Skeini) $v$ Secretary of State for Defence [2007] UKHL 26. The case is pending before the Grand Chamber of the European Court of Human Rights (Application No. 55721/07); and is subject to a public inquiry in the UK established by the Secretary of State for Defence in May 2008; http:// www.bahamousainquiry.org/.

36 The case of Private Jason Smith who died of heat stroke in a British camp in Iraq $-R$ (on the Application of Smith) v Oxfordshire Assistant Deputy Coroner [2009] EWCA Civ 441. The case was heard by the UK Supreme Court in March 2010.

${ }_{37} R$ (Gentle) v The Prime Minister [2008] UKHL 20, paras 8, 47, 53-58.

38 Bradley and Ewing (n 4) 343. 


\section{E. Reform Debate}

After the invasion of Iraq in 2003 the greater pressure within the UK is not for review of decisions to deploy troops by the Courts, but for these decisions, to paraphrase the House of Commons Select Committee on Public Administration, to be more profoundly anchored in the consent of Parliament. ${ }^{39}$ The current convention that Parliament be consulted on issues of troop deployment, it is argued, is simply inadequate when lives are at stake. ${ }^{40}$ Since Iraq there have been a number of Draft Bills suggested and put before Parliament, which, if any had been adopted, would have produced binding legislation requiring that troops should only be deployed to armed conflicts if their participation had been approved by Parliament, and, importantly, that the Government, in seeking such approval, must present reasons and legal authority. ${ }^{41}$

In discussing the issue, the House of Lords Select Committee on the Constitution stated in 2006 that in the 'absence of legal restraint on the deployment power under domestic law, the rules of international law on the use of force take on an enhanced significance as the only apparent limitation on the prerogative' ${ }^{42}$ This article has shown though that while international law has an influence on debates, it is not sufficiently determinate in the final decision to go to war. Serious doubts about the legality of the Suez operation in 1956 or the invasion of Iraq in 2003 did not stop the Government making its decisions nor did it provoke Parliament into challenging those decisions by voting against them. If clear international legal advice had been put before Parliament, it would have, arguably, been more difficult for Parliament to go along with the decision; or it might, in the case of Kosovo, for instance, have decided that the moral arguments outweighed the legal.

Unfortunately the watered down version of the reform proposal that was due to be laid before Parliament for approval before the general election in May 2010, ${ }^{43}$ was in the form of a non-binding war powers resolution, ${ }^{44}$ giving the Prime Minister maximum flexibility as to the timing of seeking approval from the House of Commons for a Government decision authorising the use of force by British armed forces outside the UK. As with the invasion of Iraq in 2003, this may mean that the timing of the vote would be such as to ensure that it is too late for the House of Commons to realistically say no. In addition, under the draft resolution, there would have been no need for the Government to seek retrospective approval when the operation is urgent or secret.

${ }^{39}$ HC Select Committee on Public Administration, 'Taming the Prerogative: Strengthening Ministerial Accountability to Parliament' HC 422, 3 (16 March 2004).

40 ibid 16.

41 ibid 35-36. See also Clare Short's Armed Force (Parliamentary Approval for Participation in Armed Conflict) Bill (22 June 2005) discussed in White (n 15) 277-278.

42 House of Lords Select Committee on the Constitution, 'Waging War: Parliament's Role and Responsibility', $15^{\text {th }}$ Report 2005-6, 27 HC 236-I, para 30 (27 July 2006).

${ }^{43}$ See statement by Jack Straw MP, Minister of Justice, to the House of Commons on 20 July 2009, which included the section: 'The Government have already announced that it would ensure that the Commons will have a pivotal position in determining whether the United Kingdom goes to war, by means of a war powers resolution. Drafts of this have already been published and will go before Parliament in the autumn'-Hansard HC vol 496105 WS (20 July 2009). The draft resolution was not laid before Parliament before its dissolution on 12 April 2010.

${ }^{44}$ UK Ministry of Justice, 'The Governance of Britain-Draft Constitutional Renewal Bill' Command Paper 7342 (March 2008), Annex A. See further Ministry of Justice, 'The Governance of Britain Review of the Executive Royal Prerogative Powers': Final Report, 15 (15 October 2009). 
Furthermore, the proposed resolution would not have required that the Attorney General make his full advice available to Parliament, though legal reasons would normally be given. This in reality represented little change from the current constitutional position and had the added advantage, from the Government's point of view, of being in a non-justiciable form thereby making sure that the Courts are not enticed into the debate about the legality of decisions to go to war.

Though concerning the most highly politically sensitive area of a State's foreign relations, international law on the use of force has increasingly penetrated the UK's constitutional structures and in so doing has compensated to a certain extent for the lack of domestic constitutional law on the matter. However, the penetration has occurred not in the Courts but in political fora where governmental control of the agenda and of the information (crucially legal advice) given to the House of Commons (and thereby the country) has arguably prevented MPs from taking a more principled stance on some of the more controversial decisions to go to war. Unfortunately, the proposed war powers resolution that was due be to be laid before Parliament in 200910 was unlikely to have changed this, lacking as it did a requirement for clear, full and balanced legal advice to be put before Parliament before a vote is taken on the deployment of troops. Fortunately, the Government ran out of Parliamentary time to put the resolution before Parliament prior to its dissolution on 12 April $2010 .{ }^{45}$ It is only to be hoped that the new Coalition Government formed after the general election on 6 May 2010 will reconsider the form and content of such an important constitutional reform. ${ }^{46}$

Nigel D White*

45 Parliamentary debates on the Constitutional Reform and Governance Bill in 2009-10 contained statements expressing regret that the issue of war powers reform was not included in the Bill. For example in the House of Commons, David Howarth MP stated that it was 'disappointing that the Government' had 'chosen not to move on other aspects of the prerogative on which they have promised to move since at least 2007 and earlier, such as war powers...'-Hansard HC vol 506 col 909 (2 March 2010). In the House of Lords, the Earl of Sandwich asked the Government to explain why it has not 'revised let alone published the draft resolution that would give Parliament a more formal vote in the process of deploying our armed forces outside the United Kingdom'; and went on to say that 'against the background of the Iraq War, this' would have been 'an important concession from the Government; it must not be allowed to disappear just because of the passage of time and when another conflict may be around the corner'-Hansard HL vol 718 col 1035 (24 March 2010). The Government Minister in the House of Lords (Lord Bach) responded that 'war powers were never in the draft Bill' being debated, and that the 'Government had concluded that they should be dealt with by way of parliamentary resolution' rather than legislation (col 1047). In an earlier debate in the House of Lords on constitutional reform Lord Tyler lamented the disappearance of proposals that would give a statutory right for MPs to vote on decisions to go to war-Hansard HL vol 716 col 1558 (28 January 2010).

46 The Conservative/ Liberal Democrat Coalition Agreement of 11 May 2010 did not mention the issue of war powers reform amongst its wide-ranging provisions on political reform—see http://www.conservatives.com/News/News_stories/2010/05/Coalition_Agreement_ published.aspx

* Professor of Public International Law, University of Nottingham, UK. The paper draws upon material in ND White, Democracy Goes to War: British Military Deployments under International Law (OUP, Oxford, 2009), and is based on papers given at the Universities of Maastricht and Uppsala. 